internationalism of recent years and its characterization of European integration as a capitalist plot. A necessary first step would be membership in ETUC (the European Union's trade union organization), which would allow the CGT to help shape the process of European integration in ways that would raise the labor and living standards of European workers. The CGT could then build on its newfound European activism to address trade unionism on a global scale, for example, by promoting human rights and helping workers in the developing world to organize. Jean-Pierre Page (National Executive Committee, CGT) rejected the inevitability of a liberal (in the European sense), Maastricht Treaty-driven European integration. Page advocated a concrete, flexible, unifying, independent, and international approach to confront the increasingly global job market and counter the weight of multinational corporations. His suggestions included new international labor legislation to penalize companies relocating to developing countries with lower labor costs; increased collaboration of union movements at the regional and interregional levels (made possible by the end of the Cold War) to maximize their influence; organizing the growing numbers of unemployed and part-time workers; replacing anachronistic and divisive ideologies by an acceptance of diversity within the international labor movement; and activism on behalf of universal issues such as human rights, peace, disarmament, and the environment. His remarks served as a fitting conclusion to a conference rich in historical perspectives and trenchant in its analyses of the challenges facing the French and international labor movements.

\title{
South Asian Labor: Linkages Global and Local
}

\author{
Dilip Simeon \\ International Institute for Asian Studies, Leiden
}

This workshop, organized by Prabhu Mohapatra and Marcel van der Linden, took place in Amsterdam in the last week of October 1995 under the joint sponsorship of the International Institute of Asian Studies and the International Institute of Social History. Twenty-two scholars from India, Europe, and the United States presented papers on a wide range of themes: labor in precolonial India, the legal regime of imperialism, the formation of class and community, South Asian labor overseas, and theoretical approaches to labor history. What impressed this participant was the high level of research and reflection that had gone into each contribution. The history of the colonial experience in Asia has been the subject of 
an immense amount of empirical research, especially into the subjugated economy and development of nationalism. Agriculture and the peasantry have taken pride of place in the constellation of themes attracting interest, which is understandable given the immense ideological impact of the Chinese revolution. This orientation has retained its appeal for new historiographic approaches, such as that of the subaltern school. During the past decade and a half, however, labor movements have also come under close scrutiny, and historians of South Asian labor have long felt the need to gather together to exchange ideas on this important and understudied subject, especially with the ongoing integration of the South Asian economies into the global market and the continued impact of labor migration. The latter has become a basis of ethnic politics as its geographical coordinates change in places as far apart as Trinidad, the Persian Gulf states, and Fiji.

The conference was held at the International Institute of Social History (IISG) in the building which houses its famous library of socialist and anarchist literature. Dirk Kolff, Sanjay Subramanyam, and P. Parthasarathy began the first session with papers on late-pre-colonial and nineteenth-century labor markets. There were two sessions on law and labor. Contributions by Ian Kerr, Patrick Peebles, John Kelly, Sabyasachi Bhattacharya, Janaki Nair, and Michael Anderson took up themes including the origins of labor legislation, the ideological and organizational determinants of the imperial labor regime, the evolution of disciplinary measures for Indian gold miners and plantation workers in British Ceylon, and the racial question in Fiji. Two sessions on labor and ethnicity dealt with questions such as work processes in mines and factories, the experience of family life in urban settings, and the interaction of traditional caste and tribe identities with structures of employment within the emerging working classes. These sessions featured papers by Ranjan Ghosh, Dilip Simeon, Arjan de Haan, Vijay Prasad, and Chitra Joshi. The experiences of Asian migrant workers-in Trinidad, Surinam, and Ceylon, and in merchant shipping-were the subject of papers by Prabhu Mohapatra (the main organizer of the conference), Rosemarijn Hoefte, and Eric Meyer. In the last session, papers by Dipesh Chakrabarty, Rajnarayan Chandavarkar, and Jan Breman (whose presence was missed) applied the concept of "difference" to Indian workers' perception of time, the marginalization of working-class historiography, and (in work linking migration and the formation of rural and urban land markets) landlessness in Asia.

The laboring experience in South Asia has been extremely varied. The persistence of precapitalist social forms and institutions in the colonial system, the emergence of a massive market for military labor, and the crucial role of the village in colonial industrialization as a source of recruitment (and a convenient substitute for the lack of municipal infrastructure) are all rich topics for further investigation. The combination of ethnicity and class in the ideological and organizational activity of Asian workers, 
and the large-scale migration, indentured and informal, of labor to mines and plantations in South Asia and overseas are likewise vast and relatively unexplored territory for historians. The conference's exploration of these and other themes within the context of global and local linkages was an excellent idea. The theoretical focus blurred sometimes, but this was partly because three days was not long enough to discuss the wide range and dense texture of the contributions.

The conference ended with a proposal to establish an Indian Labour Studies Association which would publish a newsletter and organize an ongoing series of workshops. The term "studies" rather than "history" was used in order to accommodate inquiries into contemporary movements and issues. Jan Lucassen, head of the IISG's Research Department, welcomed the proposal with an assurance of support and suggested that European labor studies would benefit greatly from an engagement with the methodological freshness and substantive empirical work which characterize South Asian labor studies. The founding meeting of this new organization will be held in India on December 15 and 16, 1996.

\title{
Aftermath: The Transition from War to Peace in America
}

\section{After World War II}

\author{
Roger Horowitz \\ Hagley Museum and Library
}

World War Two was one of the great watershed events in American history. comparable only to the American Revolution and the Civil War. It was a formative experience for the sixteen million men and women who entered the armed forces and the far greater numbers who were touched by the wal experience on the home front.

However, the legacy of the war in postwar America has been taken for granted, rather than carefully analyzed and explained. To bring greates attention to this critical transition, the Center for the History of Business. Technology, and Society at the Hagley Museum and Library sponsored $a$ conference, "Aftermath: The Transition from War to Peace in Americ After World War II," on October 26 and 27, 1995. A grant from the Delaware Humanities Forum provided partial funding for the event.

The conference opened with a keynote address by Alan Brinkley. "Legacies of World War II." Brinkley emphasized that the hopes inspirec by the war were circumscribed by the competing agendas of different sec. 